\title{
Editorial
}

Editorial

\section{The price of effective international co-operation}

One might be forgiven for assuming that during the pandemic and in particular the lockdown(s) no one has bothered a great deal about money laundering and the industry that has grown up around it. While it is true that many of us have focussed on our perceptions of survival (both professionally and personally) there are those who have seized the opportunity, not only to exploit the generosity of governments and many others, but also defraud the weak and vulnerable whether in selling them a duff face mask or miracle blessed oil to defeat the evil virus. I do not intend to attempt to chronicle let alone comment on such sadly predictable and deplorable opportunism. What is perhaps more relevant and of interest to readers of this journal and potentially even more controversial is the impact of the disruption that has taken place in international co-operation between law enforcement agencies and I am not speaking about BREXIT on this occasion!

Whether we like it or not China is a player in most commercially and financially relevant transactions in the modern world. Although the future relationship between China and the 'West' in the immediate to medium term, does not look like being characterised by good will and harmony, the reality of China's economic power is clear for all to see. China's leadership has shown a fondness for using its economic power to bully others into line. The deployment of soft power has been well illustrated in recent years in regard to those who deal with Taiwan in a way that China disapproves of. Historically Taiwan has had a lot to offer countries - across the world, in terms of intelligence and legal assistance. Indeed, until relatively recently the Taiwanese agencies were one of the very few who had any ability to address serious Chinese organised crime. This, at least at an intelligence level, became all the more important after 1997 and the gradual 'redefining' of police priorities in Hong Kong. While it is now recognised in many circles that the assumption that the Chinese establishment and triads were if not good bedfellows on speaking terms - was at least a miscalculation, the political history of Taiwan has necessitated a complex and obscured relationship between government and some perhaps dubious networks. Thus, while not always as candid and as independent as might have been hoped, agencies such as the Taiwanese Ministry of Justice's Investigation Bureau (MJIB) have been in the main, willing to assist foreign agencies. Indeed, there was a period under the presidency of Dr Ma Ying-jeou, when this was extended on a mutual basis across the Straights to the PRC.

China has for the last thirty or so years been keen to emphasise its willingness to assist and co-operate with foreign law enforcement and in particular judicial agencies. The fit, given China's civilian traditions, has not always been cosy and there are many in western agencies who distrust at least the confidentiality of communications. There is also the perception that the Chinese Communist Party has a too greater interest in what happens and before the most recent crusade against corruption, the threat of encountering corrupt officials was considered to be too great. For example, in a relatively recent case an individual who allegedly has close associations with the Snake's Head triad and operated within senior levels of the British commercial, financial and even political establishment, was alerted

Erratum: It has come to the attention of the publisher that the Editorial 23.4 in the Journal of Economic and Administrative Sciences was omitted. This error was introduced in the editorial process and has now been corrected in the online version. The publisher sincerely apologises for this error and for any inconvenience caused.

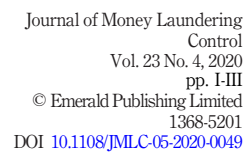


JMLC 23,4

II within 20 minutes of a request for information relating to him being received by officials in Fujian.

With President Xi Jinping's anti-corruption campaign things have changed and generally for the better. The level of corruption - perceived or otherwise, has dramatically decreased. On the other hand there is in China uncertainty as to how far old friendships and relationships - particularly in law enforcement, can now be tolerated. There was an 'old boy's network' put in place at great expense by organisations such as the Supreme People's Procuratorate which in some respects worked well. Whether these have survived the purges and institutional self-examination is questionable. Indeed, some of those who created all this are now languishing overseas beyond the reach of their former colleagues. These and other sensitivities have impacted on the quality of assistance that China gives and receives in pursing 'common' criminals let alone those who are better connected. The pandemic and China's imposition, probably contrary to at least the spirit of international law, of its new Security Law in Hong Kong has put a very large question mark against the viability of traditional mechanisms for mutual assistance. Indeed, given its policies in the South China Sea even those countries that really need China's goodwill - such as the Philippines and Vietnam are at best diffident.

China has in recent months responded by asserting its domestic and international soft power along side a good deal of rhetoric by its applauded 'wolf diplomats'. In fighting crime there is perhaps nothing new and China over its 5000 years of civilization has had the opportunity to experiment with every technique imaginable. It has, however, in its Skynet programme developed a relatively sophisticated intelligence led system which allows timely intervention to prevent suspects leaving China. It has also taken action judicially and otherwise against family members and business associates of overseas suspects. While attracting international criticism, this strategy is not noticeably different from that adopted by other countries in addressing, for example, terrorist related crime. China has also been very robust in asserting a 'long arm' jurisdiction over its nationals who have escaped overseas. There have been examples of fugitives being encouraged to surrender both themselves and their allegedly ill-gotten gains to mitigate unpleasant treatment for family and friends within China. There have also been instances of what in law amounts to kidnapping. In one case Chinese police officials simply chartered a plane flew into a foreign country and 'arrested' several Chinese fugitives. Judicial kidnappings have, of course, been resorted by other countries in extremis, including the USA. Whatever arguments may be employed justifying brining people like former Panamanian President Noriega to justice, such actions do fracture the fragile systems of international co-operation built upon respect and mutuality. China complains, with some justification, particularly in the pursuit of high profile fugitives charged with corruption that it has in fact received very little meaningful help from Western law enforcement agencies. In one case in Jilin involving the laundering of very considerable sums obtained through corruption and theft, Hong Kong, Singapore, Italy and the UK all found plausible reasons not to provide assistance, leaving the Chinese authorities with no alternative but to contemplate civil actions which resulted in a 'deal' which was criticised in the western media.

China's aspirations when it joined Interpol, with Taiwan being effectively expelled, were to become a meaningful player in international criminal justice. Indeed, China has invested in Interpol and if its candidate had not been arrested by its own agencies for corruption he would be the serving President of the organisation today. China has also made considerable efforts to render its domestic law fit for purpose. What it has not yet been able to satisfactorily address is the perception that the rule of government by law is not necessarily perceived, rightly or wrongly, by many outside China as the rule of law. Furthermore, where 
the main issue is pursing corrupt and usually highly placed officials, given the political structures within China, others are going to fear political factors are at play. Indeed, this was one of the reasons that Interpol historically was reluctant to get involved in cases of corruption. Furthermore, international police and judicial co-operation operate well only in an environment where good relations and respect are valued. The more countries move away from traditional policing to a regime based on intelligence led interventions or disruption an additional element enters the equation. Intelligence particularly in the context of the concerns of this journal, is not and can never be wholly a product of traditional law enforcement and is therefore both in its creation and utilisation often outside the operation of the usual criminal justice system. The dramatic arrest of over 800 alleged members of organised crime enterprises and seizure of $£ 54$ million, weapons and a great deal of other criminal property, by British police coordinated by the NCA (The Times, 3 July 2020) based on intelligence derived from hacking the Encrochat platform clearly illustrates this.

International co-operation in fighting crime and particularly in regard to economically motivated crime, which almost inevitably involves powerful and influential players, has and will always be problematic. The integrity, reliability and capability of overseas agencies cannot be assumed. The economic and political significance of China, however, involves considerations of a different order. While the harm resulting to the international order might be compensated for in the case of less significant players developing an effective and trusted relationship with China and its increasingly professional and sophisticated agencies is vital. While there are wider issues which need to be considered and the present circumstances do not augur well, the implications and risks of not attempting with a much greater degree of commitment and understanding to interact positively with China's legal and justice system will serve no one. 